\title{
Gun Safety and the Family Physician
}

Abortion. Legalized drugs. Assisted suicide. Guns. There are few topics in the United States that generate as much heat and debate as the topic of firearms. Why should family physicians become embroiled in this controversy and what can they do about it anyway?

Firearms cause death and injury by three different mechanisms: unintentional discharge of a gun, self-inflicted injury, and assault by another person. In 1996 in the United States, 1134 people died of wounds inflicted by unintentional discharge, 18,166 died of self-inflicted injury, and 14,037 died of assault by another person. ${ }^{1}$ It is estimated that for every fatal injury there are 16 unintentional injuries, 15 suicide attempts, and 5.3 nonfatal assaults. ${ }^{2}$ Children are at greatest risk for unintentional shootings, teens and the elderly are at greatest risk for gun suicides, and young men are at greatest risk for homicides.

Ownership of guns and keeping them in the home does increase the risk of violent death, both from homicide ${ }^{3}$ and suicide. ${ }^{4}$ There has been a long, heated, and for the most part nonproductive debate about gun control in this country in an attempt to address the great number of deaths and injuries caused by guns. Although physicians have been involved in this debate, their involvement certainly has not been without controversy. ${ }^{5,6}$

More recently attention has focused on safe storage of guns for a number of reasons. The youth homicide rate from guns has decreased, in some cities dramatically, during the last 5 to 6 years. ${ }^{7}$ Police efforts to trace the origin of guns ${ }^{8}$ and crack down on illegal gun owners appear to be very successful. For example, in Boston police efforts to stop gun carrying by youth have resulted in a near elimination of gun homicides of young men. ${ }^{9}$ In addition, numerous studies have shown that many homes, including those with children, contain guns

Submitted 13 April 1999.

From the I Iarborview Injury Prevention and Research Center, and the Departments of Pediatrics and Epidemiology, University of Washington, Seattle. Address reprint requests to Frederick P. Rivara, MD, MPH, Box 359960, 325 Ninth Ave., Seattle, WA 91804. that are not stored safely, ie, unlocked and either loaded or stored with the ammunition. In a national telephone survey, Hemenway et $\mathrm{al}^{10}$ found that $14 \%$ of firearm owners with children in the household stored firearms unlocked and loaded. Senturia and colleagues ${ }^{11}$ found that $7 \%$ of parents surveyed in pediatricians' offices had at least one firearm not stored safely.

Proper storage of guns has the potential to decrease unintentional shootings of children as well as the impulsive use of guns in suicides by teens and the elderly. It could also prevent the theft of the 500,000 guns stolen each year in the United States. ${ }^{12}$ Importantly, safe storage of guns crosses the political spectrum and is supported by the American College of Physicians, ${ }^{13}$ the American Academy of Pediatrics, ${ }^{14}$ the National Rifle Association, ${ }^{15}$ and the Sporting Arms and Ammunition Manufacturers' Institute. ${ }^{16}$ The question, then, is how to increase the proportion of guns that are stored safely?

One method is through health education to individual patients by their physician. Shaughnessy and colleagues ${ }^{17}$ in this issue of the $7 A B F P$ describe a survey of patients in 11 family practices in Pennsylvania concerning the role of their family physician in counseling families about gun ownership and storage. Most respondents did not think their physician was a particularly good source of information on the topic, did not believe it was the physician's responsibility, and did not think gun safety should be discussed during office visits. The fear of physicians that they might offend some patients by discussing gun safety was borne out by the experience of one practice conducting the survey. The local magistrate and board of directors forced the medical director to discontinue the survey after 1 week. One could imagine that the response to actually giving advice would have been even stronger!

How likely is it that such advice would be followed if given? No randomized controlled trials have yet been reported on the effectiveness of physician advice on firearm safety and storage. A recent systematic review of the literature on the effective- 
ness of interventions in the clinical setting has found that some are effective in increasing the adoption of some safety practices, but not others. ${ }^{18}$ Interventions have been effective for increasing use of child restraints, ownership of smoke detectors, and lowering of tap water temperatures to safe levels. Isolated counseling sessions about bicycle helmet ownership and making homes childproof, however, were not effective. In addition, the primary care physician is constantly bombarded with exhortations to do more, such as screen for domestic violence, conduct brief interventions for smoking and alcohol misuse, and screen patients for a wide variety of illness, while getting less reimbursement for care delivered.

Community-wide interventions might be more applicable and successful, although again, no studies have been conducted on the effectiveness of interventions to improve the proportion of homes that store guns safely. Community programs to increase bicycle helmet use, for example, have been successful in increasing use and reducing bicyclerelated head injuries. ${ }^{19}$ Similar trials focused on safe storage of guns are urgently needed.

A different approach would be legislation to improve safety of guns stored in the home. In 1989 Florida passed legislation that included criminal penalties for gun owners if an unsupervised child younger than 16 years was injured or injured someone else with a gun. Fifteen states have now passed such laws, and many others are considering such legislation. A national evaluation of these laws found that they were associated with a $23 \%$ reduction in unintentional shooting deaths among children younger than 15 years. ${ }^{20}$ Such an effect might be far more powerful than isolated counseling by physicians in their offices.

The problem of firearm injuries is not likely to disappear from the national scene anytime soon. A focus on safe storage of guns might be the most appropriate and feasible approach right now. It is clear that interventions in this area should be based on firm scientific evidence and use creative and innovative approaches to make a difference in the long run.

$$
\begin{array}{r}
\text { Frederick P. Rivara, MD, MPH } \\
\text { Seattle, Wash }
\end{array}
$$

\section{References}

1. National Center for Injury Prevention and Control, Centers for Disease Control and Prevention Web site. Available at http://www.cdc.gov/ncipc/osp/ mortdata.htm. Accessed (Au, add date accessed).

2. Kellermann AL, Rivara FP, Lee RK, et al. Injuries due to firearms in three cities. N Engl J Med 1996; 335:1438-44.

3. Kellermann AL, Rivara FP, Rushforth NB, et al. Gun ownership as a risk factor for homicide in the home. N Engl J Med 1993;329:1084-91.

4. Kellermann AL, Rivara FP, Somes G, et al. Suicide in the home in relation to gun ownership. $N$ Engl J Med 1992;327:467-72.

5. Kassirer JP. Private arsenals and public peril. N Engl J Med 1998;338:1375-6.

6. Kassirer JP. A partisan assault on science-the threat to the CDC. N Engl J Med 1995;333:793-4.

7. Homicide trends in the United States, 1976-1997. Bureau of Justice Statistics Web site. Available at www:ojp.usdoj.gov/bjs/homicide/homtrnd.htm. Accessed 15 May 1999.

8. Bureau of Alcohol, Tobacco, and Firearms. ATF, the Youth Crime Gun Interdiction Initiative: performance report for the Senate and House Committees on Appropriations, pursuant to conference report 105-825, October 1998. Washington, DC: Department of the Treasury, Bureau of Alcohol, Tobacco, and Firearms, 1999.

9. Kennedy DM, Piehl AM, Braga AA. Youth violence in Boston: gun markets, serious youth offenders, and a use-reduction strategy. (Kids, Guns and public Policy). Law and Contemporary Problems 1996;59:14796.

10. Hemenway D, Solnick SJ, Azrael DR. Firearm training and storage. JAMA 1995;273:46-50.

11. Senturia YD, Christoffel KK, Donovan M. Gun storage patterns in US homes with children. A pediatric practice-based survey. Arch Pediatr Adolesc Med 1996;150:265-9.

12. Cook PJ, Molliconi S, Cole TB. Regulating gun markets. (Guns and Violence Symposium). J Criminal Law Criminology 1995;86:59-92.

13. Firearm injury prevention. American College of Physicians. Ann Intern Med 1998;128:236-41.

14. American Academy of Pediatrics Committee on Injury and Poison Prevention. Firearm injuries affecting the pediatric population. Pediatrics $1992 ; 89(4 \mathrm{Pt}$ 2):788-90.

15. A parent's guide to gun safety. Fairfax, Va: National Rifle Association Safety and Education Division, 1995.

16. Firearm safety depends on you. Wilton, Conn: Sporting Arms and Ammunition Manufacturer's Institute, 1997.

17. Shaughnessy AF, Cincotta JA, Adelman A. Family practice patients' attitudes toward firearm safety as a preventive medicine issue: a HARNET study. J Am Board Fam Pract 1999;12:000-00. 
18. DiGuisepopi C, Roberts I. Individual-level injury prevention strategies in the clinical setting. In Future of Children, 2000. In press.

19. Rivara FP, Thompson DC, Thompson RS, et al. The Seattle children's bicycle helmet campaign: changes in helmet use and head injury admissions. Pediatrics 1994;93:567-9.

20. Cummings P, Grossman DC, Rivara FP, Kocpsell TD. State gun safe storage laws and child mortality due to firearms. JAMA 1997;278:1084-6. 